\title{
THE EFFECT OF THE ECONOMIC PERFORMANCE OF A SCIENCE PARK ON AIR QUALITY: AN EMPIRICAL STUDY OF HSINCHU SCIENCE PARK IN TAIWAN
}

\author{
HUANG, S. Z. ${ }^{1}-$ CHAU, K. Y. ${ }^{2}-$ YIN, F. ${ }^{3}-$ CHEN, Q. ${ }^{4 *}$ \\ ${ }^{I}$ School of Economics and Management, Guangdong University of Petrochemical Technology \\ Maoming, China \\ ${ }^{2}$ Faculty of International Tourism and Management, City University of Macau, Macau, China \\ ${ }^{3}$ Institute of City Governance, Shenzhen University, Shenzhen, China \\ ${ }^{4}$ Zhongshan Institute, University of Electronic Science and Technology of China \\ Zhongshan, China \\ *Corresponding author \\ e-mail: zschenquan@gmail.com; phone: +86-0760-8832-1738; fax: +86-8867-6939-663
}

(Received $4^{\text {th }}$ Sep 2018; accepted $15^{\text {th }}$ Oct 2018)

\begin{abstract}
Science parks have become important factors in the development of global economy. However, the development process of Hsinchu Science Park, with economic growth at the same time, cause serious air pollution that needs to be investigated. The influence of the economic development on air quality is an important research topic. Vector Auto Regression model (VAR) was used to analyze the effect of R\&D funding, and of the operating performance on the air pollution index (PSI). The results show that there is a long-term stable relationship between R\&D funding, the operating performance and PSI. There is a significant relationship between R\&D funding, park performance and deferred effect; the management performance of the Science Park has a significant pulse response on PSI with a relatively short impact cycle. To improve the air quality, the government should pay attention to the issue of environmental impact during the economic development and management of science parks.
\end{abstract}

Keywords: science park, air pollution, $R \& D$ funding, VAR simulation, impulse response function

\section{Introduction}

Global warming has affected the survival of humans. What is more, the serious air and environmental pollution, such as haze, acid rain, ozone, and so on, are being continuously generated by the economic development of the countries (Yam et al., 2004; Afroz et al., 2003; Huang et al., 2016). However, environmental conflicts and pollution problems still occur in the science park that claims to represent high-tech industry with low pollution, low energy consumption, and high value-added. This issue has been debated in the environment and economic development field (Hoffman, 2000). The 2014 data from World Health Organization showed that the main source of air pollution is gasoline exhaust, coal-fired power plants, and industrial emissions. And the pollution is gathering in some developing countries with a large population. Taiwan Hsinchu Science Park follows the example of the first successful science park "Silicon Valley" in the USA. It has been recognized as the world's fastest-growing science park with the best-operating efficiency, and the best technological innovation ability after 30 years of development (Huang et al., 2016). Also, the American magazine, SIT SELECTION, once rated Taiwan Hsinchu Science Park as one of the world's top ten fastest growing 
science parks in 2001. Besides, after the completion of the park, the residents there have protested several times for air pollution, water pollution and waste disposal problems. Therefore, environmental agency has continued to detect air quality around the park. Given the above statements, some questions are generated. For example, whether hightech Science Park is more environmentally friendly or whether the high-tech industries in the park with easier assessment to national research funding would impact on business performance and air quality. As a result, the development of Science Park and the impact on air quality worth further research.

The science park is an important carrier of economic development and high-tech industry development and has been widely developed around the world. Gore (1984) proposed in the study of regional planning and promoting economic development that Science Parks can promote economic growth and create jobs through investing parks and thereby bringing regional economic development (Huang et al., 2016). Hsinchu Science Park plays an important role in development and technological innovation in the high-tech industry (Chen and Huang, 2004; Lai and Shyu, 2005) and as a policy tool to promote national or regional economic development (Wessner, 2011). Behind these positive benefits, environmental pollution, traffic congestion, health and safety, and other negative effects conflict constantly (Douthwaite, 1992). According to Berry and Rondinelli (1998), the enterprise development should first assess the impact on the environment. Besides, environmental pollution is one of the assessment indicators determining whether the science park can be on behalf of high-tech industry and is also a part of the investment in environmental outcomes (Huang et al., 2008). The environmental risk which may occur by the setting of the science park includes gas, wastewater discharge, and so forth. Meanwhile, Hsinchu Science Park is an important foundation for industrial growth in Taiwan. Therefore, it is particularly important to consider how to make government departments and the public to understand the impact of science park development to air quality and it is also an important basis for the government to develop the science park and make environmental management policies.

Science Park, having been developed for a half century, has come to a more mature and stable stage regarding both the development in theory and practices. Moreover, both domestic and international literature contain many research papers on science parks, which mostly focus on the economic development contribution. Science park research mainly focused on two aspects: parks and vendors. Considering park aspect, the research is mainly carried out with macro perspective and focuses on planning and site selection, park management, industrial agglomeration, technology management, and so forth. Whereas, in vendor aspect, the research is mainly carried out with micro perspective and focuses on parks vendor management, manufacturers and industry, and so on. However, there is little research on the local economy contribution and air quality impact after the completion of the science park. In this research, the Vector Auto Regression (VAR) model analysis is used to explore the air quality impacted by the science park development. Many scholars around the world widely used VAR model to study the relationship between economic growth and environmental pollution (Narayan et al., 2008; Nasir and Rehman, 2011; Li et al., 2009; Lv, 2010). Moreover, VAR model is applied to verify whether Science Park is more environmentally friendly, and whether the government R\&D funding policy is valid. VAR model not only has practical significance in theory, but also provides the government with references to develop and manage the Science parks.

The following sections of this research are as follows. Section two describes the 
definitions and related literature review of Science parks and air quality. Section three is research design which includes data sources, variable definitions and analysis instruments. Drawing on the sample of Hsinchu Science Park, an empirical analysis of the park development impacts on air quality is conducted in section four. Last, the conclusion and implications are provided.

\section{The influence of science park and air quality}

\section{Science park}

Science Park also as Technology Park is the industrial area developed by the government and is a form of reflection of the economy park without the inclusion of industrial park. The basic proposal of the Science parks is to foster and gather vendors and agencies which pay attention to research and development so as to develop hightech industries. Science Park is an industrial cluster formed by a country or a regional government according to its economic development stage and its demand for economic development. Science park gathers all kinds of production factors through various ways as administrational and markets'. Also, Science park conducts science integration within a certain space to make it a functional layout optimization, reasonable hierarchy, industry distinctive industrial cluster ( $\mathrm{Li}$ and Chen, 1987). Originated in the Stanford Research Park established in 1951, USA, the Science Park is created on the foundation of industrial park development. In order to create a favorable environment for high-tech industries, the science park relies on knowledge-intensive and technical superiority. Through the implementation of various high-tech-related preferential policies such as tax relief and perfect service system, the science parks create industrial cluster advantages and industrial environment which attract and gather talented persons, techniques, and capital and then accelerate the industrialization of high-tech achievements.

Taiwan Science Park was established by the Ministry of Science and Technology and local governments. Hsinchu Science Park, established in 1980, is managed and constructed by the Ministry of Science and Technology, the coordinates are $24.7829 \mathrm{~N}$, $121.0058 \mathrm{E}$ (as shown in Figure 1). The aim of science parks is to shape Taiwan's highquality research and development, production, work, humane leisure environment to attract persons talented in high-tech, the introduction of high technology, the establishment of high-tech industry base, and to promote Taiwan's industrial upgrading and economic development. The early vendors in the park primarily operate electronic manufacturing services, but now, the science parks have developed into one of the world's most intensive areas of semiconductor manufacturing. At the end of 2012, the Hsinchu Science Park had about 485 high-tech vendors stationed, and the major six industries include semiconductor, computer, communications, optoelectronics, precision machinery industry, and biotechnology. Also, the science park employs over 140,000 people and applies technology projects for up to three thousand patents. The whole industry paid-in capital is approximately over one trillion NT dollars, and 43.7 billion NT dollars have been put into R\&D funding. Moreover, business performance has achieved one trillion NT dollars. All the achievements directly or indirectly led to the development of high-tech industry and the upstream and downstream industries, which had a huge contribution to the high-tech industry. Factors which affect the development of the science park are varied. Both internal condition factors and external 
environmental factors would influence the development of the science park. Many scholars believe that the reason for the excellent performance of Hsinchu Science Park is not only because of a superior geographical advantage, quality human resources and good infrastructure, but also the perfect environment for investment, research and development incentives and other measures.

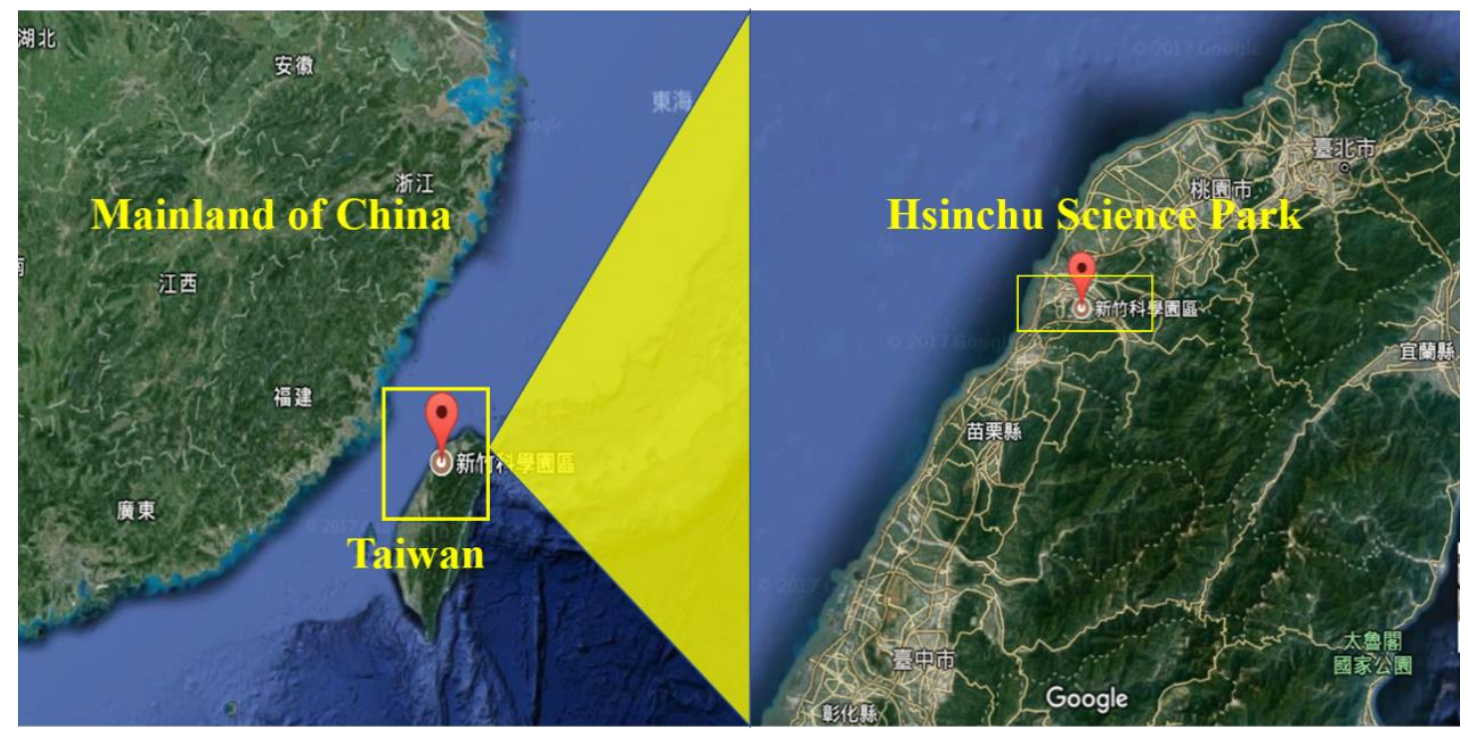

Figure 1. Location of Hsinchu Science Park in Taiwan

\section{Performance}

Performance is an important indicator of the competitiveness of the organization as well as one of the hottest topics of the world economy and management field. To measure whether the science park is successful or not, a series of key elements including the park's promotion to the regional economic development and its contribution to GDP is available. The performance of Science Park is affected by the result of various factors, and the performance is mostly the primary assessment indicator for park development. Park performance typically includes management units' performance and organizational performance, such as: planning, management system, service system, and so on. In this research, the performance means business performance which is the simplest and most direct indicator to assess performance (Wu et al., 2006; Hung et al., 2008). The total turnover is the accumulation of science park vendors' net sales (Including the declaration of sales, the sum of receipts, sales returns and discounts, and pre-sales adjustments) minus deductible items (Including collection and payment, the sale of fixed assets, sale of scrap, interest income, and sample giving). Therefore, this research regards park business performance as a measure of output variables of performance.

\section{Research \& Development}

Research and Development (R\&D) is an important element influencing innovation. The enterprises keep obtaining economic profits by creating new products or services through $R \& D$. R\&D fund means the expenses from $R \& D$ activities which is often used as an important variable to measure the impact of research and innovation and 
performance as well (Yu et al., 2009; Chiou et al., 2011; Duqi et al., 2011; Yang, 2011; Fan and Case, 2010; Huang et al., 2016). Furthermore, the input variable of the operating efficiency of the high-tech industry is measured by R\&D funding (Wu et al., 2006). Schumpeter (1934) claimed that generally speaking only large enterprises can access R\&D funding. The big enterprises would create excess profits so that they can keep investing in $R \& D$ activities and then reach the enhancement of the competitiveness of enterprises and economic profit. However, there is a positive relationship between the $R \& D$ funding expenses and the enterprises' performance. What is more, the R\&D expenditures have a deferred effect on the enterprises profit rate (Wu et al., 2006).

\section{Air quality}

Air quality closely relates to the health and quality of our lives. 25 March 2014 World Health Organization's data showed that air pollution had become the world's biggest environmental health risks. With the rapid economic growth and a high degree of industrialization, activities related to air pollution also increase and result in a large number of emissions of air pollutants. Thus, the importance of air pollution control work has been highlighted. In order to monitor the composition and concentration of various air pollutants and to understand the real-time status of air quality, Pollutant Standard Index (PSI) is used as the standard (Ott and Hunt, 1976; EPA, 1994). PSI indicators have been widely used in the United States, Canada, Europe, Australia, China, Taiwan, and so forth (Cairncross et al., 2007; Cheng et al., 2007). Based on the monitoring data and its impact on human health, the sub-index values of different pollutants are converted separately, and then the maximum value of each sub-index is marked as the air pollution index values of the station at the date. The degree of PSI values distributed from 0 to 500, thus, a higher value of PSI means more severe air pollution. Besides, PSI with health influence relationship is divided into five levels: "Good", "Moderate", "Unhealthy", "Very Unhealthy", and "Hazardous" (see Table 1). The major air pollutants in PSI value include five sub-indicators: sulfur dioxide $\left(\mathrm{SO}_{2}\right)$, ozone $\left(\mathrm{O}_{3}\right)$, nitrogen dioxide $\left(\mathrm{NO}_{2}\right)$, carbon monoxide $(\mathrm{CO})$, suspended particles $\mathrm{PM}_{10}$. One of the pollutants with the highest concentration will be selected as PSI value. The source of air pollution in science parks can be divided into two aspects. Emissions including exhaust, dust, the use of chemical substances, and volatile organic solvents which are discharged into the air due to the imperfectness of process or control of equipment, and the exhaust emissions of cars and motorcycles. Song et al. (2008) confirmed the existence of the EKC phenomenon from the environmental indicators of wastewater, waste gas and solid waste in the science park.

Table 1. PSI value and influence on health

\begin{tabular}{c|c}
\hline PSI & Influence on health \\
\hline $0 \sim 50$ & Good \\
\hline $51 \sim 100$ & Moderate \\
\hline $101 \sim 199$ & Unhealthy \\
\hline $200 \sim 299$ & Very Unhealthy \\
\hline$\geqq 300$ & Hazardous \\
\hline
\end{tabular}


Many scholars consider economic development and environment as the situation of "cannot have your cake and eat it". But, Grossman and Krueger (1995) stated that with no environmental policy intervention, in the early stages of economic development, a country or regional environmental quality and pollution will deteriorate with the improvement of per capita income levels. However, when economic development and per capita income levels rise to a certain extent, environmental quality and pollution will improve as per capita income levels improve. That is, it shows an inverted U-shaped curve line relationship between environmental quality and per capita income level.

\section{Research design}

\section{Measurement model}

VAR Model was put forward by Sims (1980) who integrated Economics in the model and promoted the widespread application of dynamic economic system analysis. VAR model is usually applied to explain the impact of various economic impacts on the formation of economic variables by predicting interconnected time series system and analyzing the dynamic effect of random disturbance to the variable system. VAR model is able to analyze the dynamic effects of the system between each variable and longterm dynamic effect between each variable avoiding the problem of variable defect (Lütkepohl, 1993). Also, VAR model can solve the bias problem of endogenous variables. The Impulse Response Function analysis from VAR model is adopted by this research to analyze the short-term effect of the development of the Science Park on the influence on air quality. The model is established by making every endogenous variable as for lag value function of endogenous variables in the system. The second lag order of each variable is the independent variable of the equation and the measurement model equations are as followed.

$$
\begin{aligned}
\mathrm{PSI}_{t}= & B_{0}+\sum_{p=1}^{2} \theta_{11 p}\left(P S I_{t-p}\right) \\
& +\sum_{p=1}^{2} \theta_{12 p}\left(P_{t-p}\right) \\
& +\sum_{p=1}^{2} \theta_{13 p}\left(R \& D_{t-p}\right)+\varepsilon_{1 t}
\end{aligned}
$$

In the equation, the dependent variable PSI is air pollution index. $P$ is performance of park operating performance. $R \& D$ means the research and development funding. $B_{0}$ is the coefficient needed to estimate, $t$ means time, and $\varepsilon$ is a constant.

\section{Variables description}

The independent variables in this study are $R \& D$ funding and performance as the dependent variable is the air quality of the science park, meaning PSI. This research aims to explore the impact of R\&D funding and performance on PSI. The operational definitions of the variables are shown in Table 2. This research controls the influence of industrial environmental factors on performance and chooses high homogeneity analysis sample (Boulding et al., 1990; Chu et al., 2004). The research object of industrial 
structure contains six industries in the science park: the integrated circuit, computer peripherals, telecommunications, optoelectronics, precision machinery and biotechnology.

Table 2. The definitions of research variables

\begin{tabular}{c|c|c|c}
\hline Abbreviation & Variables & Measurement & Unit \\
\hline PSI & $\begin{array}{c}\text { Air Pollution } \\
\text { Index }\end{array}$ & $\begin{array}{c}\text { Follow the standard released by the testing report } \\
\text { data from environmental agency. }\end{array}$ & \\
\hline P & Performance & $\begin{array}{c}\text { Vendors' cumulative balance of net sales which } \\
\text { is according to the total turnover count by the } \\
\text { science park. }\end{array}$ & $\begin{array}{c}\text { Hundred } \\
\text { million } \\
\text { USD }\end{array}$ \\
\hline R\&D & $\begin{array}{c}\text { Research \& } \\
\text { Development } \\
\text { funding }\end{array}$ & $\begin{array}{c}\text { Refers to the funding from the government's } \\
\text { R\&D funding. This research follows the } \\
\text { technical statistical findings from the Ministry of } \\
\text { Science and Technology. }\end{array}$ & $\begin{array}{c}\text { Million } \\
\text { USD }\end{array}$ \\
\hline
\end{tabular}

\section{Data source}

The sample of this study is Hsinchu Science Park, one of the world's top ten fastestgrowing science parks. According to Yin (2003), Case study can specifically present the complexity and comprehensiveness of the decision factors and processes. Data is mainly adopted from the official website of Hsinchu Science Park, statistical database of the Ministry of Science and Technology, and web air quality statistics from the Environmental Protection Department. The science park PSI data have been recorded since 2001, so this study collected a total of 12 years data from 2001 to 2012.

\section{Statistical analysis}

In this study, Eviews6.0 was used to do the empirical analysis of the regression equation and to verify the assumptions of this study. In addition, stability analysis and co-integration test was made to analyze the data. The Impulse Response was tested using R\&D funding and performance to PSI.

\section{Empirical analysis}

\section{Variable balance test}

This research employs ADF (Augmented Dickey Fuller Test) to test the stability of the variables. The results are shown in Table 3. In order to ensure the residual nonautocorrelation, the best lag phase is confirmed by the minimum criterion of AIC. As shown in Table 3, all standard sequences of the variables are unstable but have passed first order difference stability.

According to the analysis of Table 3, time series are all unstable, so cointegration test, proposed by Johansen (1995), is needed. The test helps to confirm whether the liners of those unstable variables are stable series and to identify the existence of the long-term stable relationship between those variables. 
Table 3. Unit and test results

\begin{tabular}{cccc}
\hline Variables & $\begin{array}{c}\text { Testing Type } \\
(\mathbf{c}, \mathbf{T}, \mathbf{d})\end{array}$ & ADF Statistics & Test results \\
\hline LnPSI & $(\mathrm{C}, 0,0)$ & $-1.5303 /$ & Unstable \\
\hline $\mathrm{D}(\mathrm{LnPSI})$ & $(\mathrm{C}, 0,1)$ & $-4.3272^{* *}$ & Stable \\
\hline LnP & $(\mathrm{C}, 0,0)$ & -2.2141 & Unstable \\
\hline $\mathrm{D}(\mathrm{LnP})$ & $(\mathrm{C}, 0,1)$ & $-4.1115^{* *}$ & Stable \\
\hline LnR\&D & $(\mathrm{C}, 0,0)$ & -2.3824 & Unstable \\
\hline $\mathrm{D}(\mathrm{LnR} \& \mathrm{D})$ & $(\mathrm{C}, 0,1)$ & $-3.7603^{* *}$ & Stable \\
\hline
\end{tabular}

Notes: ( $c, T, d)$ Equations means the test contains intercept, time trend and lag order. Lag order follows the minimum standard of SC. D(X) means the first order difference of X. * means passing $10 \%$ significance, $* *$ means passing $5 \%$ significance, and ***means passing $1 \%$ significance. The assumptions are rejected under the above three circumstances

The results are presented with co-integration equation as follows.

$$
\begin{gathered}
\mathrm{Ln} P S I_{t}=-0.2629 \mathrm{Ln} P_{t}+0.0636 \mathrm{Ln} R \& D_{t} \\
(0.0137)
\end{gathered}
$$

The co-integration equation shows that PSI has a long-term stable relationship with $\mathrm{P}$ and R\&D. $1 \%$ increase in the performance of Science Park led to $0.26 \%$ increase in the air pollution index. $1 \%$ increase in governments' R\&D funding investment led to $0.06 \%$ decrease in the air pollution index.

\section{Impulse response function analysis}

Impulse Response Function Analysis refers to the impact of random disturbance with one standard deviation on the current and future values of other variables. The analysis can intuitively depict the dynamic interaction and effect between variables. This research focuses on the impact of independent variables within a system of changes in each period of air pollution index as well as the relative contribution of the dependent variables to independent variables in the system. The Impulse Response Function Analysis of VAR model shows the short-term dynamic analysis between the Hsinchu Science Park, the air pollution index, operating performance, and R\&D (see Figs. 2 to 7). The horizontal axis in the figure represents the lag periods of impulse response and here it shows 10 periods. The vertical axis represents the impulse response function value, which means the response size of dependent variables on the argument. The blue solid line is the path changes of the impulse response function value over time. Two red dashed lines are the confidence bands of twice the standard deviation.

Fig. 2 shows that response of performance to performance converges at the lowest point of the second period. As shown in Figure 2, the Science Park focuses on export processing while fewer companies invest in improving the business environment steadily. Fig. 3 reflects the impulse response function produced by a positive impulse of the Science Park performance to PSI. With a positive impulse, the second period is a 
negative response and the third period reach the maximum positive response. Then the fifth period drops to the maximum negative response, while the sixth and seventh period rise to a positive response. Finally, the convergence happened right after the eighth period. Overall, Fig. 3 shows that the influence of performance growth on current PSI is not obvious, but it has more significant influence on the subsequent which shows a smaller fluctuation.

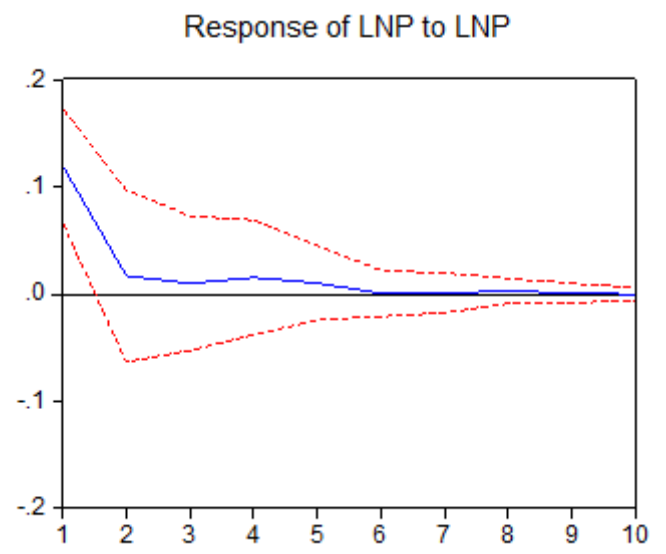

Figure 2. Response of $L N P$ to $L N P$

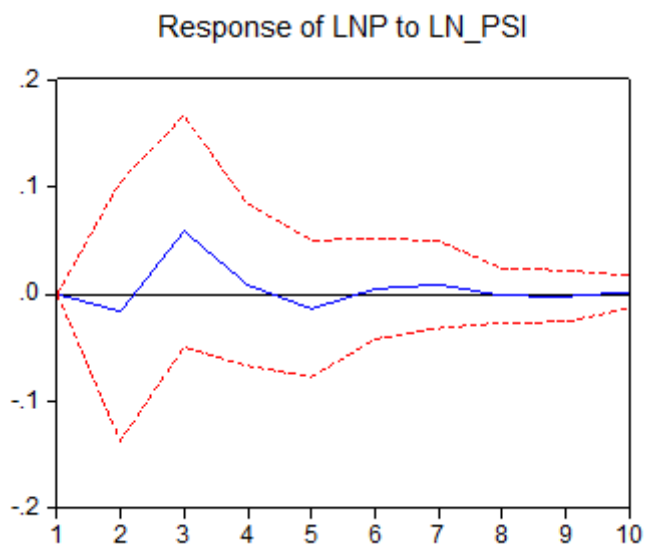

Figure 3. Response of LNP to LN_PSI

Fig. 4 reflects the impulse of one standard deviation's impact on PSI. In Fig. 4, starting with a positive response, convergence comes at the minimum positive response of the fourth period which shows the positive impulse response to Science Park's PSI. Fig. 5 shows that after PSI giving a positive impulse to performance, a positive response turns into a negative response at the second period and convergent at the fourth period with the maximum positive response. All in all, Fig. 5 reflects that PSI has a nonsignificant result to performance.

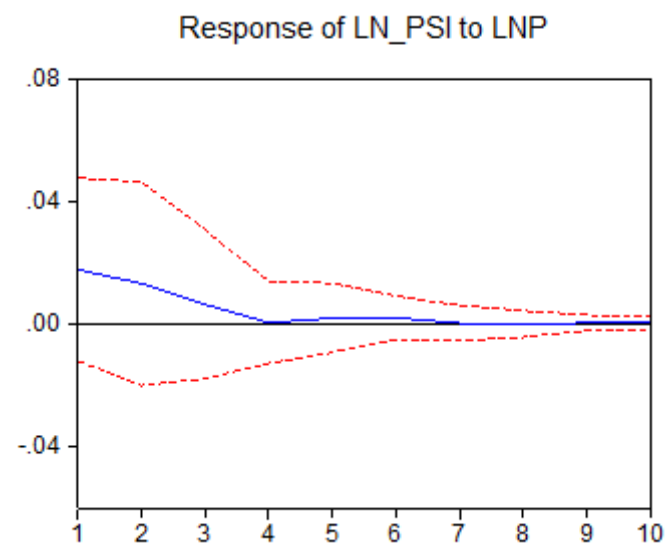

Figure 4. Response of LN_PSI to LNP

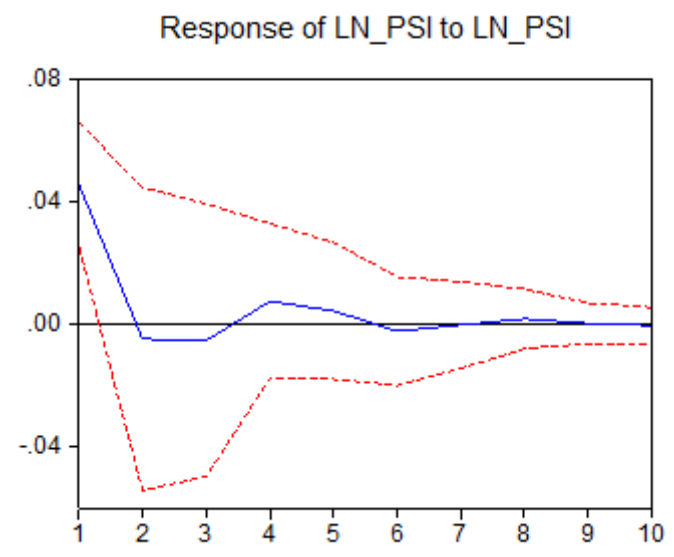

Figure 5. Response of LN_PSI to LN_PSI

Fig. 6 reflects that a positive impulse of $R \& D$ funding impacts the performance which turns from negative response to positive response. In Fig. 6, the second period 
reaches the minimum negative response while period three to six gradually turns into a positive response and then the maximum response is reached at the eighth period with a steady stable status followed. Moreover, Fig. 6 indicates that the government's investment of R\&D funding has a deferred effect to Science Park performance persistently. As to Figure 7, a positive impulse of R\&D funding impacts the PSI with a positive response. In Fig. 7, the second period reaches the maximum positive response while period three to six gradually steadily decreases and then converges right after the seventh period. Therefore, Fig. 7 reflects that government's investment of R\&D funding is mainly used for product development and production.

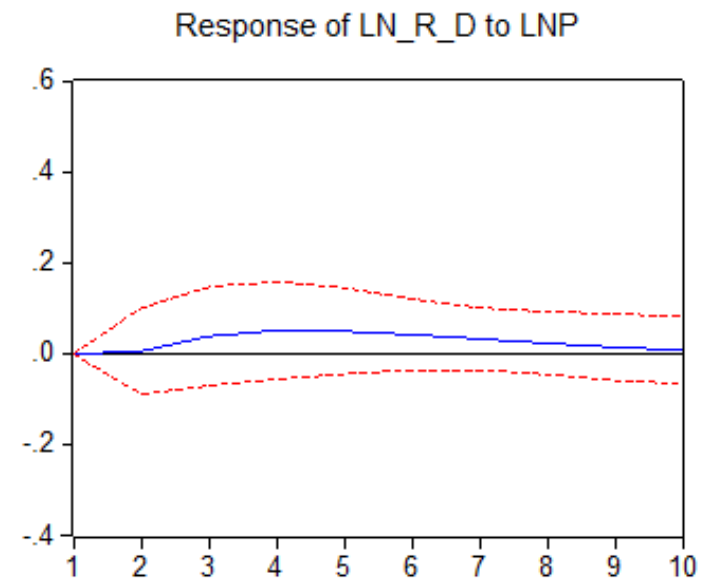

Figure 6. Response of $L N \_R \& D$ to $L N P$
Response of LN_R_D to LN_PSI

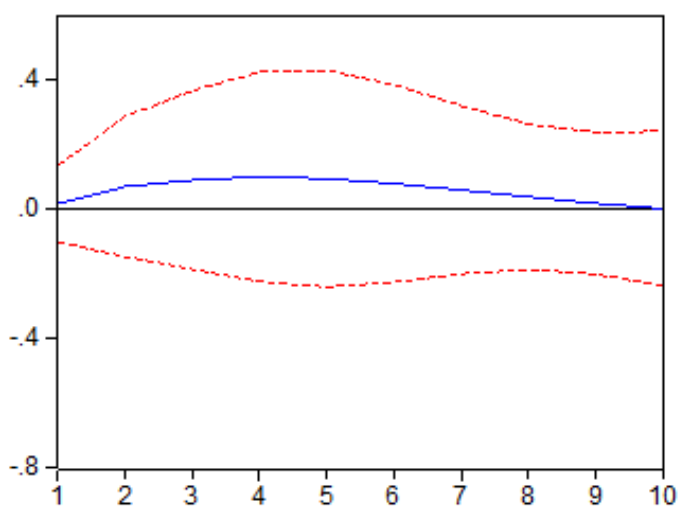

Figure 7. Response of $L N \_R \& D$ to $L N \_P S I$

To determine the degree of impact of Science Park development on air quality, a variance decomposition analysis is conducted to analyze performance and R\&D funding to PSI. Variance decomposition means that each endogenous variable in the system is decomposed according to the factor and is composed with disturbance variances of each related equation as to understand the relative importance of information to the endogenous variable of the model. Based on the VAR model, results from variance decomposition analysis of each variance are shown in Table 4. The number in the table indicates the contribution rate.

Table 4. Variance decomposition table of Ln PSI

\begin{tabular}{ccccc}
\hline Period & S.E. & LN_PSI & LN_R_D & LNP \\
\hline 1 & 0.030106 & 100.0000 & 0.000000 & 0.000000 \\
\hline 2 & 0.041555 & 56.91400 & 0.584914 & 42.50109 \\
\hline 3 & 0.047293 & 49.50826 & 17.33988 & 33.15186 \\
\hline 4 & 0.052935 & 47.80735 & 25.72957 & 26.46308 \\
\hline 5 & 0.055049 & 46.18966 & 29.33487 & 24.47546 \\
\hline 6 & 0.057580 & 44.50632 & 32.98266 & 22.51102 \\
\hline 7 & 0.059900 & 43.03423 & 36.05004 & 20.91572 \\
\hline 8 & 0.061717 & 41.88578 & 38.22949 & 19.88474 \\
\hline 9 & 0.063132 & 41.08339 & 39.68306 & 19.23355 \\
\hline 10 & 0.064158 & 40.49282 & 40.71018 & 18.79700 \\
\hline
\end{tabular}


Table 4 shows that PSI is influenced by its own impulse because its own disturbance decreases to $56 \%$ in the second period and becomes stable around $40 \%$ during the third period. The disturbance from performance tends to decrease and becomes stable around $19 \%$ at the eighth period which shows that performance influences air pollution. As to $\mathrm{R} \& \mathrm{D}$ funding, the disturbance tends to increase meaning that $\mathrm{R} \& \mathrm{D}$ funding has a significant effect on performance and has an impact on air quality.

\section{Conclusion and Implications}

This research explores the impact of R\&D funding and performance on air quality using data of Taiwan Hsinchu Science Park from 2001 to 2012 by conducting the impulse response function analysis of VAR model. The result shows that R\&D funding and performance have a long-term stable relationship with the air pollution index, PSI. According to the finding of impulse response function analysis, performance has a significant impact on air pollution index and has a deferred effect. The investment of $R \& D$ funding has a significant effect on performance, but $R \& D$ funding has no significant effect on air quality. R\&D funding has a deferred effect on performance with a constant stable effect. R\&D funding is mainly used for product development and production so that $\mathrm{R} \& \mathrm{D}$ funding has a significant effect on air pollution index.

Therefore, the enterprises in Science Park mainly focus on export processing which needs intensive traditional labors without high level modernization of high-tech production technology. Under the R\&D funding policy, the enterprises in Science Park can improve the performance through product development which confirms the applicability and effectiveness of R\&D funding policy.

Air quality does not decrease as the performance grows. That is, science parks with high-tech industries as core industries are relatively environmentally friendly. According to the statistics of environmental protection from park administration, more than 50 million NT dollars has been invested in and the statistics also confirm the effectiveness of Science Park management department. However, R\&D funding has no significant influence on air quality. The result shows that park enterprises focus more on product development rather than technology development through the production process. It is suggested that governments should adopt high R\&D capability, high-tech products, and modern technology as the standard of the investment.

In the past, Taiwan overvalued the development of economic and ignored the protection of ecology and environment. With the improved environmental awareness of the government and the people, economic developments with ecological damages are disfavored. However, with the strategy of science parks development as improvement on technological innovation and economic development, economic development, environmental preservation, and sustainable development issues are bound to become a dilemma. The fundament of air pollution prevention is avoiding and reducing the generation and emission of air pollutants. Schreiner (1988) regarded that companies' promoting environmental activities are primarily from external pressures and automatically change. The sustainable development of science parks includes the two aspects of science parks and enterprise.

(1) Science parks aspect

Science Park is the key to prevent or decrease air pollution. Also, Science Park air pollution policy should turn to predict prevention. First, Science Park should, following 
national and local regulations or standards, conduct environmental impact assessment, pollution permits, and pollution centralized processing to prevent or decrease air pollution. Also, vendors with environmentally friendly products or technology should be selected. Second, the Science Park should establish centralized pollution treatment facilities and emergency response plan, improve the internal management system, prevent or reduce emissions of air pollutants due to improper management or operations. Finally, the Science Park should promote environmental management system, establish reward or compensation for clean production or green products, and make single pollution control become pollution prevention to reach an ecology park. In response to global climate change, the development of green energy industry as well as higher environmental standards for factories have become the consensus for countries worldwide.

\section{(2) Enterprise aspect}

Environmental capacity will be one of the company's future strategies for sustainable development and competitiveness. Under the environmental pressure, the enterprises must adjust operational strategies with sustainable development (Hammer, 1996). The air pollutants produced during operation might come from raw materials from sources, the process of manufacturing and delivery, or air pollutant emissions may also occur due to improper management or operation. Enterprise can promote ISO14000 environmental management system, clean production, energy management, carbon emissions, green supply chain, green products, identification of environmental pollution, establishment of a management system, and improvement and implementation on controlling or reducing air pollutants to reduce pollution prevention costs, save (or recycle) raw materials or products, improve production efficiency and quality, avoid the occurrence of workers' occupational disease, and thereby reduce operating costs. Enterprises preventing air pollution should recognize environmental factors and air pollutants to avoid or reduce air pollution through operating technology, improving process, and perfecting management system. The enterprise should set up ventilation collection system in air pollution source to prevent the particulate and gaseous air pollutants equipment and then discharge the clear air from the chimney to the atmosphere ensuring air quality and protecting human health.

There are many factors influencing air quality; for example, detection error, climate change, and seasonal fluctuations can influence PSI value. Further analysis needs to be conducted for the interaction causes of hazardous substances, such as $\mathrm{SO}_{2}, \mathrm{O}_{3}, \mathrm{NO}_{2}, \mathrm{CO}$, $\mathrm{PM}_{10}$, and so forth. Meanwhile, different enterprises might have different impacts on air quality which require further research.

Acknowledgements. This study was supported by "Guangdong Social Science Planning Project" (GD17XGL15).

\section{REFERENCES}

[1] Afroz, R., Hassan, M. A., Ibrahim, N. A. (2003): Review of air pollution and health impacts in Malaysia. - Environmental Research 92: 71-77.

[2] Berry, M. A., Rondinelli, D. A. (1998): Proactive corporate environmental management: A new industrial revolution. - Academy of Management Executive 12: 38-50. 
[3] Boulding, W., Richard, S. (1990): Environment, market share, and market power. Management Science 36(10): 1160-1178.

[4] Cairncross, E. K., John, J., Zunckel, M. (2007): A Novel Air Pollution Index Based on the Relative Risk of Daily Mortality Associated with Short-term Exposure to Common Air Pollutants. - Atmos. Environ. 41: 8442-8454.

[5] Chen, C. J., Huang, C. C. (2004): A multiple criteria evaluation of high-tech industries for the science-based industrial park in Taiwan. - Information and Management 41: 839-851.

[6] Cheng, W., Chen, Y., Zhang, J., Lyons, T. J., Pai, J., Chang, S. (2007): Comparison of revised air quality index with the PSI and AQI indices. - Total Environ 382: 191-198.

[7] Chiou, C. C., Wang, Y. M., Wei, C. L., Chien, T. C. (2011): The effects of innovation and human capital investments on the operating efficiencies of Taiwan's IC design industry. Sun Yat-Sen Management Review 19(2): 343-385.

[8] Chu, P. Y., Tzeng, G. H., Teng, M. J., Chiu, H. (2004): A multivariate analysis of the relationship among market share, growth and profitability-The case of the science-based industrial park. - Sun Yat-Sen Management Review 12(3): 507-533.

[9] Douthwaite, R. J. (1992): The Growth Illusion. How Economic Growth Has Enriched the Few, Impoverished the Many and Endangered the Planet. - Dublin: The Lilliput Press Ltd.

[10] Duqi, A., Mirti, R., Torluccio, G. (2011): An analysis of the R\&D effect on stock return for european listed firms. - European Journal of Scientific Research 58(4): 482-496.

[11] EPA. (1994): Measuring Air Quality: The Pollutant Standards Index. - EPA 451/K-94001.

[12] Fan, Y., Case, F. M. (2010): Evidence of R\&D effects on cross sectional stock returns. Academy of Accounting and Financial Studies Journal 14(3): 31-41.

[13] Gore, C. (1984): Regions in Question: Space, Development Theory and Regional Policy. - London: Mathuen, Inc. 106-121.

[14] Grossman, G. M., Krueger, A. B. (1995): Economic growth and the environment. Quarterly Journal of Economics 110: 353-377.

[15] Hammer, W. B. (1996): What's is The Relationship Among Cleaner Production, Pollution Prevention, Waste Minimization and ISO 14000?. First Asian Conference on Cleaner Production in Chemical Industry, Dec. 9-10, Taipei.

[16] Hoffman, A. J. (2000): Competitive Environmental Strategy, Island Press, Washington, DC.

[17] Huang, S. Z., Wu, T. J., Tsai, H. T. (2016): Hysteresis effects of R\&D expenditures and patents on firm performance: An empirical study of Hsinchu Science Park in Taiwan.Filomat 30(15): 4265-4278.

[18] Huang, W. M., Lee, W. M., Wu, C. C. (2008): GHG emissions, GDP growth and the Kyoto Protocol: A revisit of Environmental Kuznets Curve hypothesis. - Energy Policy 36(1): 239-247.

[19] Johansen, S. (1995): Likelihood-Based Inference in Cointegrated Vector Autoregressive Model. - Oxford: Oxford University Press.

[20] Lai, H. C., Shyu, J. Z. (2005): A Comparison of innovation capability at science parks across the Taiwan Strait: The case of Zhangjing high-tech park and Hsinchu sciencebased industrial park. - Technovation 25: 805-813.

[21] Li, K. T., Ch'en, M. T. (1987): China's economic development strategy General. - Linking Publishing, Taipei.

[22] Li, L., Zhu, J. S., Gao, R. X. (2009): The study on relationship between economic growth and environmental pollution in chongqing base on VAR model. - Journal of Southwest University 31(11): 92-96.

[23] Lütkepohl, H. (1993): Introduction to Multiple Time Series Analysis. - Springer-Verlag.

[24] Lv, J. (2010): Economic growth and environmental pollution in Shanghai: An empirical analysis based on VAR model. - China Economic Management 24(8): 1-6. 
[25] Narayan, P. K., Narayan, S., Prasad, A. (2008): A structural VAR analysis of electricity consumption and real GDP: Evidence from the G7 countries. - Energy Policy 36(7): 2765-2769.

[26] Nasir, M., Rehman, F. U. (2011): Environmental Kuznets Curve for carbon emissions in Pakistan: An empirical investigation. - Energy Policy 39 (3): 1857-1864.

[27] Ott, W. R., Thom, G. C. (1976): A critical review of air pollution index systems in the united states and Canada. - J. Air Poll. Control Assoc 26: 460-470.

[28] Schumpeter, J. (1934): The Theory of Economic Development. Harvard University Press.

[29] Sims, C. A. (1980): Macroeconomics and reality. - Econometrica 48: 1-48.

[30] Song, T., Zheng, T. G., Tong, L. J. (2008): An empirical test of the environmental Kuznets curve in China: A panel cointegration approach. - China Economic Review 19: 381-392.

[31] Wessner, C. W. (2011): Growing Innovation Clusters for American Prosperity: Summary of a Symposium. - USA: National Academies Press.

[32] Wu, W. Y., Tsai, H. J., Chang, K. Y., Lai, M. K. (2006): Assessment of intellectual capital management in Taiwanese IC design companies:Using dea and the malmquist productivity index. - R\&D Management 36(5): 531-547.

[33] Yam, C. M., Guan, J. C., Pun, K. F., Tang, P. Y. (2004): An audit of Technological Innovation Capabilities in Chinese Firms: Some Empirical Findings in Beijing, China. Research Policy 33(8): 1123-1250.

[34] Yang, C. C. (2011): A study for the relationship of the banking loans, the ratio of r\&d expenditure ratio and the performance of debt enterprises. - Journal of International Management Studies 6(2): 1-11.

[35] Yin, R. K. (2003): Case study research: Design and methods (3rd ed). - Thousand Oaks, CA: Sage.

[36] Yu, H. C., Wang, W. Y., Chang, C. (2009): The Pricing of Intellectual Capital in the IT Industry. Working paper. - National Chengchi University. 